УДК 633.25.013:005.21

DOI: $10.15673 /$ fie.v11i4.1546

\author{
Агеєва I.M. \\ кандидат економічних наук, доцент \\ кафедра менеджменту та логістики \\ E-mail: agejeva@ukr.net \\ ORCID ID: 0000-0002-9493-5493 \\ Агаркова О.В. \\ завідуюча лабораторією \\ кафедра менеджменту та логістики \\ Одеська національна академія харчових технологій \\ вул. Канатна, 112, г. Одеса, Україна, 65039 \\ E-mail: violaagarkova@gmail.com \\ ORCID ID: 0000-0001-7261-7120
}

\title{
ВПРОВАДЖЕННЯ ФУНКЦІОНАЛЬНИХ СТРАТЕГІЙ НА ПІДПРИЄМСТВАХ ВИНОРОБНОЇ ГАЛУЗІ
}

У статті розглянуто порівняння регіонів України з виробництва виноматеріалів. Визначено позитивні та негативні тенденції функціонування виноробної галузі, виділені основні проблеми їі розвитку. Визначено значення стратегічного управління, як ефективного способу реакції підприємства на зміну зовнішнього середовища і його внутрішніх можливостей.

Наведено класифрікацію стратегій як по ієрархії, так і за конкурентними ознаками, а також виявлені основні компоненти цих стратегій і їх зміст. Визначено місце кожного виду стратегій в системі стратегій підприємства, що особливо важливо для прийняття правильних управлінських рішень. Визначено роль і місце функціональних стратегій підприємства, таких як: маркетингова, виробнича, фрінансова, організаційних зміни, соціальна, НДДКР і екологічна. Визначено напрямки стратегічного розвитку підприємств виноробної галузі, розроблено систему функціональних стратегій для виноробного підприємства та надані пропозиції щодо розробки стратегічних альтернатив на прикладі ТОВ «ПТК Шабо», запропоновано стратегічний набір на ТОВ «ПТК Шабо».

Ключові слова: стратегічне управління, функціональна стратегія, виноробна галузь, виноробство, система стратегій.

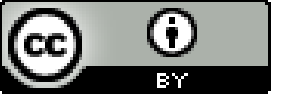

This work is licensed under a Creative Commons Attribution 4.0 International License http://creativecommons.org/licenses/by/4.0/
Постановка проблеми та її зв'язок з важливими науковими та практичними завданнями. Нестабільність бізнес-середовища зумовлює необхідність вирішення проблем гнучкої адаптації підприємств до зовнішніх змін у процесі досягнення цілей їх розвитку. Відповідно до цих змін та умов функціонування підприємств змінюються методи прийняття управлінських рішень стає нагальною потреба щодо застосування стратегічного управління. У зв'язку 3 цим особливої актуальності набуває пошук альтернативних рішень в системі функціональних стратегій підприємства.

Аналіз останніх публікацій по проблемі. Економічні проблеми виноградарства і виноробства та актуальність стратегічного управління розглядалися у працях Шершньвої 3.С., Томпсона А. А., Стрікленда А. Д. Аакера Д., Мінцберга Г., Альстренда Б., Портера М., Врігта П., Прінгле П., Моклера Р., Агеєвої І. М., Боярської М.О., Міщенко А.П., Крусір Г. В., Бутенко Н.В. та.

Формулювання цілей дослідження. Метою статті є впровадження функціональних стратегій на підприємствах виноробної галузі.

Для досягнення поставленої мети необхідно вирішити такі основні завдання:

- визначити роль та місце функціональних стратегій;

- розробити стратегічний набір функціональних стратегій для підприємства виноробної галузі;

- запропонувати можливі заходи щодо формування функціональних стратегій для виноробного підприємства .

Виклад основних результатів та їх обгрунтування. Для ефективного функціонування підприємств у сучасних, економічно складних умовах необхідні нові прогресивні моделі господарювання, до яких відноситься стратегічне управління.

Стратегічне управління $є$ ефективним засобом своєчасної реакції підприємства на зміну його внутрішніх можливостей і зовнішнього середовища. Стратегічне управління використовується 3 метою: підвищити ефективність роботи, тобто забезпечити чітке розуміння цілей і завдань усіма співробітниками підприємства, навчити їх оптимально використовува- 
ти ресурси, враховувати реальні можливості, гнучко реагувати на зміни в навколишньому середовищі [3].

Процедура розробки стратегії передбачає визначення бажаного стану підприємства: бачення місії, цілей і конкретних заходів щодо використання силь- них (слабких) сторін для досягнення можливостей (нівелювання загроз).

Для досягнення мети дослідження розглянемо систему стратегій підприємства, які можуть застосовуватись на різних рівнях (рис. 1).

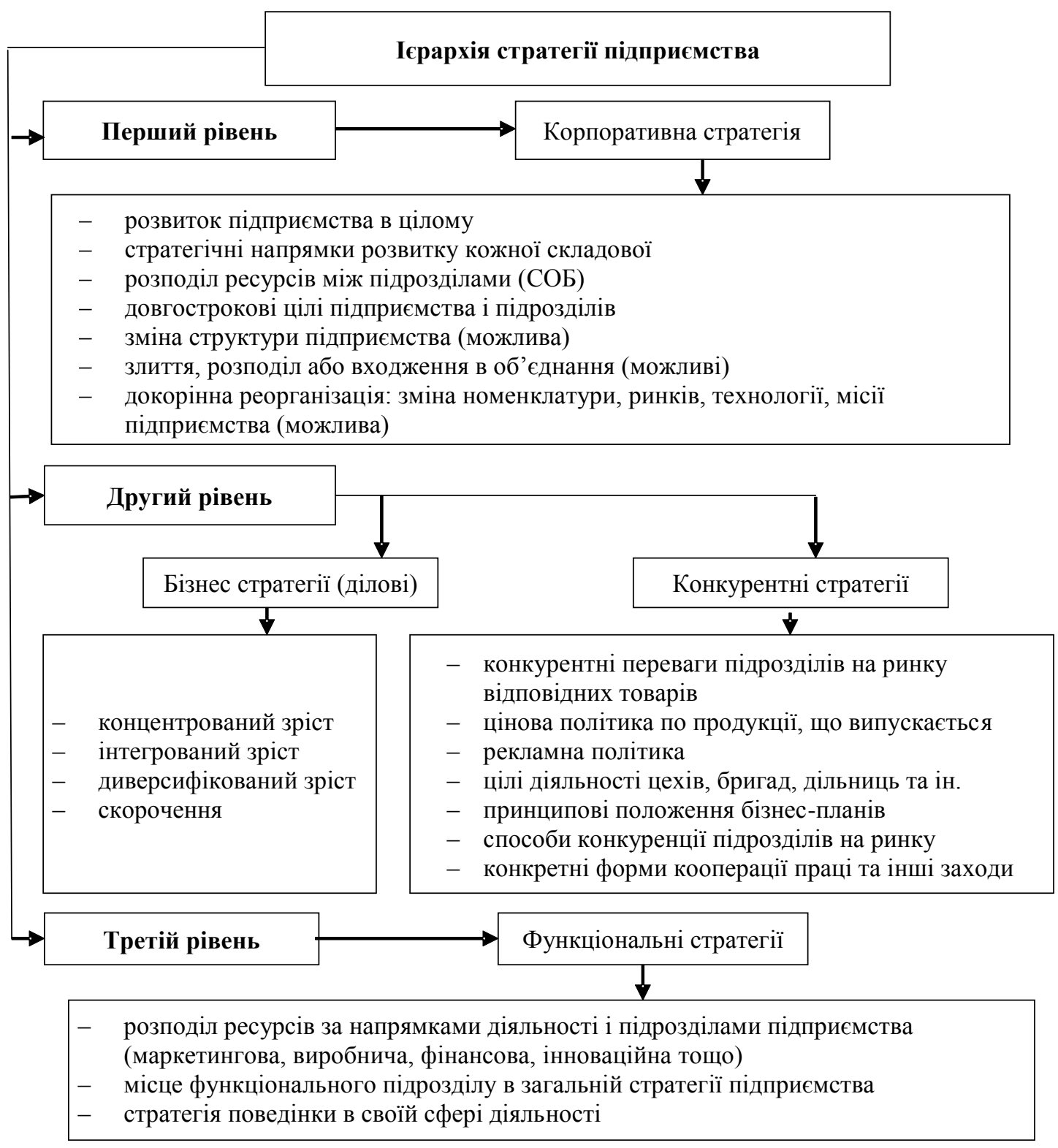

Рис. 1. Система стратегій підприсмства*

* розроблено авторами на підставі [6]

Визначення шляхів впровадження стратегічного управління на підприємствах виноробної галузі відбувається за допомогою розробки саме функціональних стратегій.

Функиіональна стратегія - це стратегія для кожного функціонального напряму діяльності диверсифікованої чи вузькоспеціалізованої компанії. Підприємство має використовувати стільки функціональних стратегій, скільки у нього основних напрямів діяльності: стратегія маркетингу, виробництва, фінансова стратегія, інноваційна стратегія, стратегія управління персоналом тощо. Вони надають конкретику, допомагають довести корпоративну і конкурентні стратегії до функціональних підрозділів господарської діяльності. Одночасно функціональні підрозділи мають значний вплив при формуванні корпоративної і конкурентних стратегій [7].

В Україні виноробна галузь - це складова ча- 
стина загальнонаціонального продовольчого комплексу. Та, на жаль, вітчизняний ринок винограду і вина перебуває нині в кризовому стані. Сьогодні площі виноградників України становлять близько 44 тис га, що у чотири рази менше порівняно з 1990 роком [9].
Втративши півострів, ми позбулися великого виробника вина: в Криму розташована п'ята частина українських виноградників і приблизно стільки ж заводів 3 переробки винограду, які постачали п'яту частину виноматеріалу (див.табл.1).

Виробництво виноматеріалів за регіонами у 2018 році*

Таблиця 1

\begin{tabular}{|c|c|c|c|c|c|c|}
\hline Регіони & $\begin{array}{c}\text { Обсяг вироблених } \\
\text { виноматеріалів, т }\end{array}$ & $\begin{array}{c}\text { У \% до } \\
2017 \\
\text { року }\end{array}$ & $\begin{array}{c}\text { для шам- } \\
\text { панського та } \\
\text { ігристих вин }\end{array}$ & столові & кріплені & інші \\
\hline Україна & $\mathbf{1 9 7 4 9 7 2 0 , 7}$ & $\mathbf{1 0 5 , 5}$ & $\mathbf{5 0 7 9 9 3 8 , 6}$ & $\mathbf{9 2 7 9 0 7 3 , 9}$ & $\mathbf{2 7 9 9 4 8 , 9}$ & $\mathbf{6 6 3 0 5 , 8}$ \\
\hline Миколаївська & 6697927,0 & 104,9 & 2058380,2 & 2913237,6 & - & - \\
\hline Одеська & 11028105,5 & 112,4 & 2932320,3 & 5659045,1 & - & - \\
\hline Херсонська & 1792329,0 & 82,1 & 89238,1 & 483487,8 & - & - \\
\hline
\end{tabular}

*дані наведено без урахування тимчасово окупованої території Автономної Республіки Крим,

м. Севастополя та частини тимчасово окупованих територій у Донецькій та Луганській областях;

*складено автором на підставі [9]

Дані табл.1 відображають обсяги виноматеріалів, вироблених 31 грудня 2017 року до 30 листопада 2018 року підприємствами, які мають власні переробні потужності або їх орендують та здійснюють перероблення винограду.

Найбільшу частку в структурі виробництва виноматеріалів та переробки винограду займає Одеська область, у 2018 році переробка винограду становить 11,028 млн.т., що складає $33,91 \%$ у загальному обсязі. Це обумовлено тим, що в Одеській області зосереджені найбільші площі насаджень [9].

На території Одеській області сконцентрована найбільша кількість найвідоміших виноробних підприємств України. Це ПрАТ «Одесавинпром», ТОВ «ПТК Шабо», ПрАТ «Болградський виноробний завод», ПрАТ «Ізмаїльський виноробний завод» та інші заводи.

Процес впровадження функціональних стратегій досліджується на одному з провідних підприємств Одеської області - ТОВ « Промисловоторговельна компанія Шабо».

TOВ «ПТК Шабо» - вертикально інтегрований виноробний холдинг з повним циклом виробництва, на основі винограду він випускає всі види алкогольної продукції. Виробничі потужності компанії розташовані в с. Шабо Одеської області. Компанія ретельно працює над тим, щоб після завезення європейських сортів винограду пристосувати їх до природно-кліматичних умов Шабо, поліпшити їх властивості, а також вирощувати свої унікальні сорти винограду, які ідеально підходять для наших вин та коньяків $[6,8]$.

Слід зазначити, що компанія “Шабо” створює витончені вина, коньяки та відроджує виноробні традиції України, покращуючи ії імідж, повертає культуру, пов'язану з вживанням вина. Для досягнення цих цілей компанія постійно інвестує свої матеріальні та інтелектуальні ресурси в розвиток виноградарства та виноробства, а також в соціально значущий проект підвищення культури споживання алкогольної продукції для народу України $[1,2]$.
Для виноробного підприємства ТОВ «ПТК Шабо» проведено стратегічний аналіз внутрішнього $\mathrm{i}$ зовнішнього середовища. На основі цього аналізу для підприємства пропонується відповідний стратегічний функціональний набір (рис. 2).

В межах стратегічного набору для підприємства ТОВ «ПТК Шабо» запропоновані заходи за основними функціональними стратегіями.

Маркетингова стратегія є визначальною серед інших функціональних стратегій. Вона визначає найефективніші маркетингові заходи, які забезпечують реалізацію корпоративної, конкурентних, ділових і функціональних стратегій підприємства [7].

До заходів маркетингової стратегії для нашого підприємства ми віднесли такі:

1. Розширення асортименту.

Пропонуються такі види розширення асортименту, як «Rezerv» для бізнес-класу; слабоалкогольні вина та сортові види горілки.

Пропонуються слабоалкогольні вина через те, що в останні роки поширюється здоровий образ життя та багато споживачів дезорієнтовані антиалкогольної рекламою. Переважними стають легкі вина, які краще вписуються в "сучасний стиль споживання продуктів харчування" [11].

Також пропонується випуск сортових видів горілки: треба поділяти виноматеріал на сорти та 3 них виробляти горілку, наприклад, горілка виноградна «Мускатна Шабо» чи горілка виноградна Шардоне [11].

\section{2. Вихід на нові ринки.}

Підприємство ТОВ «ПТК Шабо» націлено на експорт в інші країни і вже зайняло багато закордонних ринків. Однак багато країн ще не охоплені. Тому пропонується вихід на ринки таких країн як Китай, Японія та Америка. В першу чергу потрібно зосередитись на Японії, тому що ринок вина в країні не дуже розвинутий, та невелика кількість конкурентів, чого не можна сказати про Китай та Америку [11].

3. Реклама в 3МI. 


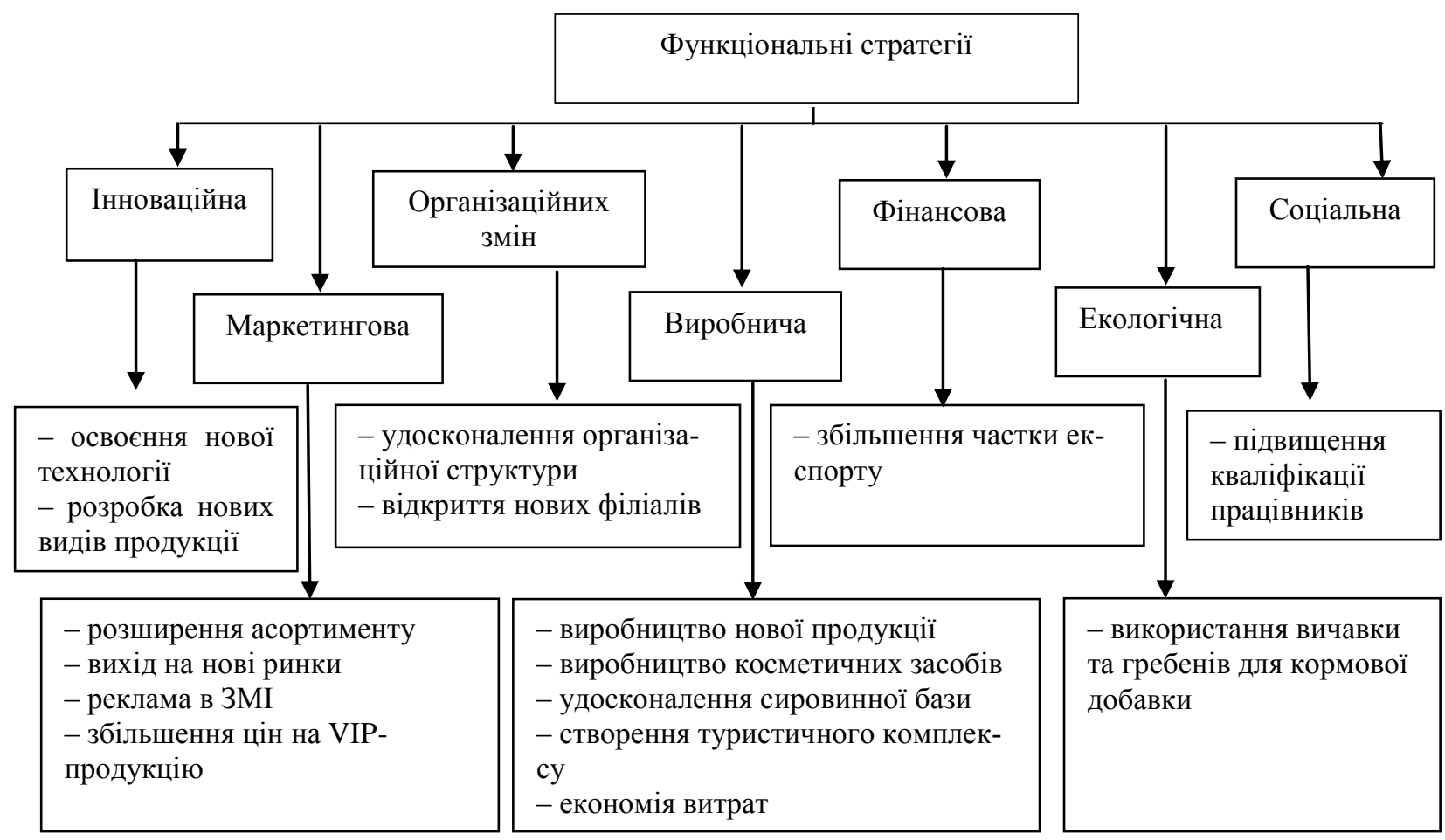

Рис. 2. Функціональний стратегічний набір для підприємства ТОВ «ПТК Шабо»* * авторська розробка

В Україні діє закон про заборону рекламування алкогольних напоїв з 6:00 до 23:00. Однак можна бути спонсором популярної телепередачі або якоїсь події.

4. Збільшення цін на VIP-продукцію.

Підприємство використовує відносно привабливу цінову політику, однак рекомендовано збільшити ціни на VIP-продукцію, тому що існує певний цільовий сегмент споживачів, орієнтований саме на такі вина [12].

Виробнича стратегія забезпечує досягнення певних рівнів розвитку виробництва [7]. Для нашого підприємства запропоновані такі заходи:

1. Виробництво косметичних засобів.

Пропонується на основі відходів основного виробництва. Наприклад, можна робити 3 виноградних кісточок масло для тіла та скраб.

2. Удосконалення сировинної бази.

Пропонується ввести в структуру насадження столових сортів винограду. Це може збільшити зацікавленість туристів та садоводів до підприємства [12].

3. Економія витрат. Пропонується використання лози для опалення приміщень, що призведе до значної економії .

Фінансова стратегія відповідає за прогнозування і коригування фінансових потоків відповідно до нових стратегій підприємства [7].

Зараз частка експорту підприємства становить 3\%. Для ТОВ «ПТК Шабо» пропонується в рамках фінансової стратегії збільшення частки експорту 3 $3 \%$ до $7 \%$, що дозволить отримувати дохід в більш стабільній валюті. Задля цього потрібно освоювати нові ринки.
Стратегія організаційних змін - впроваджується для того, щоб організація швидко адаптувалася до умов мінливого зовнішнього оточення [6].

Для підприємства пропонується:

1. Удосконалення організаційної структури за рахунок утворення системи департаментів по основним напрямкам діяльності [11].

2. Створення туристичного комплексу. Для того, щоб вважатись туристичним комплексом, ТОВ «ПТК Шабо» не вистачає готелю. Шабо розташовано біля чорного моря та багатьох баз відпочинку, це дозволить залучити більше відвідувачів та дозволить отримувати більший прибуток [11].

3. Відкриття нових філіалів.

В зв'язку з тим, що в Грузії розташовані виноградники та завод підприємства ТОВ «ПТК Шабо», пропонується відкрити в Грузії новий філіал «Центру культури вина Шабо».

Також пропонується відкрити новий філіал в Одесі, оскільки це туристичне місто, в якому буде: фірмовий магазин, дві зали дегустації: перша - звичайний, а друга - для VIP-клієнтів. Також в Одеському філіалі пропонується відкрити школу сомельє, де робітники ресторанного бізнесу зможуть поліпшувати кваліфікацію [11].

4. Покращення інфраструктури.

Інфраструктура в Шабо не є досконалою, дороги розбиті, тому пропонується зробити причал та пустити паром з міста Одеси в Шабо. Також пропонується зробити додаткову зупинку для електрички. Залізничний транспорт зупиняється на далекій відстані, тому додаткова зупинка буде розташовуватись недалеко від Дому ігристих вин Шабо [12]. 
Інновачійна стратегія - це стратегія створення нової продукції за інноваційною технологією та впровадження прогресивної техніки і технології [7].

Вище зазначено, що нами запропоновано створення нових видів продукції, для більшості треба нові лінії та технології.

Також треба розробити відповідну технологію для виробництва косметичних засобів [10].

Соціальна стратегія - передбачає створення незалежної соціальної інфраструктури для нормального відтворення і відновлення затраченого трудового потенціалу [7].

Кадри - це дужа важлива складова кожного підприємства, тому слід покращити умови праці і організаційну культуру. Пропонується організовувати спільні корпоративні заходи, які покращать взаємовідносини всередині колективу та дозволять оновити трудові якості, а також заходи $з$ покращення умов праці та заохочення працівників [9,3].

Екологічна стратегія - передбачає заходи по збереженню довкілля від можливих негативних наслідків для екології, впровадження безвідходного виробництва [7].
В Одеській національній академії харчових технологій були проведені дослідження щодо корисності відходів виноробного підприємства [13]. На базі цих досліджень пропонується для виноробного підприємства використання відходів виробництва (вичавків та гребнів) для отримання кормової добавки, яка збагатить раціон харчування тварин та дозволить підприємству підвищити ефективність [13].

Висновки та напрями подальших досліджень. Було розглянуто сучасний стан виноробної галузі, а саме порівняння регіонів України по виробництву виноматеріалів. Наведена ієрархія видів стратегії та визначення місця функціональної стратегії.

Також було розроблено набір функціональних стратегій для виноробного підприємства. Визначено напрямки стратегічного розвитку підприємств виноробної галузі, надано пропозиції щодо розробки стратегічних альтернатив для ТОВ «ПТК Шабо», запропоновано заходи, щодо впровадження на ньому функціональних стратегій.

Показано вплив запропонованих заходів на покращення діяльності по основним функціональним напрямкам та виноробного підприємства у цілому.

\section{Література}

1. World Statistics of the Wine Institute: web-site. URL:

http://www.wineinstitute.org/resources/statistics(viewed on: 15.09.2019)

2. 15 Of The Most Effective Wine Marketing Tactics: web-site. URL: https://marketing.sfgate.com/blog/15of-the-most-effective-wine-marketing-tactics(viewed on: 20.09.2019)

3. Aaker David A. Strategic Market Management. Wiley, 2013. 336 p.

4. Mockler R. J. Strategic Management: An Integrative Context-Specific Process. Harrisburg-London: Idea Group Publishing, 1992. 246 c

5. Wright P. L., Pringle C. D., Kroll M. J. Strategic management: text and cases,. Boston: Allyn and Bacon, 1992. $969 \mathrm{c}$.

6. Публикація документів Державної Служби Статистики України: офіційний веб-сайт. URL: https://ukrstat.org (дата звернення: 5.09.2019)

7. Мозоленко M.C. Функціональні стратегії в загальноорганізаційному розвитку підприємства URL: http://dspace.nuft.edu.ua/jspui/bitstream/123456789/21462/1/23.pdf (дата звернення: 5.09.2019)

8. Аграрний сектор розвитку України (стан і перспективи розвитку)/ Присяжнюк М.В. та ін.; за ред. М.В. Присяжнюка, М.В. Зубця, П.Т. Саблука, В.Я. Месель-Веселяка, М.М. Федорова. К.: ННЦ ІАЕ, 2011. $1008 \mathrm{c}$.

9. Головне управління статистики в Одеській області: веб-сайт. URL: http://www.od.ukrstat.gov.ua

10. Агєєва I.M., Мілєва М.Д. Стратегія конкуренції як основа досягнення конкурентних переваг харчових підприємств. URL: http://www.nbuv.gov.ua/ old_jrn/Soc_Gum/Ekhp/2009_3/st6.pdf. (дата звернення: 11.09.2019)

11. Агеєва I.М., Агаркова О.В. Дослідження стратегій розвитку на підприємствах виноробної галузі // Економіка харчової промисловості. 2017. Т. 9, Вип. 4. С. 35-42. doi: 10.15673/fie.v9i4.741

12. Агеєва I. М., Агаркова О.В. Планування розвитку підприємства на основі розробки стратегічного набору // Економіка харчової промисловості. 2018. Т. 10, Вип. 2. С. 60-68. doi: 10.15673/fie.v10i2.961

13. Крусір Г.В., Соколова І.Ф. Тверді відходи - екологічні аспекти виноробного підприємства // Екологічна безпека. 2012. № 2. С. 112-115. 


\author{
Агеева И.Н. \\ кандидат экономических наук, доцент \\ кафедра менеджмента и логистики \\ E-mail: agejeva@ukr.net \\ ORCID ID: 0000-0002-9493-5493 \\ Агаркова О.В. \\ заведующая лабораторией \\ кафедра менеджмента и логистики \\ Одесская национальная академия пищевых технологий \\ ул. Канатная, 112, г. Одесса, Украина, 65039 \\ E-mail: violaagarkova@gmail.com \\ ORCID ID: 0000-0001-7261-7120
}

\title{
ВНЕДРЕНИЕ ФУНКЦИОНАЛЬНЫХ СТРАТЕГИЙ НА ПРЕДПРИЯТИЯХ ВИНОДЕЛЬЧЕСКОЙ ДЕЯТЕЛЬНОСТИ
}

В статье рассмотрено современное состояние винодельческой отрасли, а именно - сравнение регионов Украины по производству виноматериалов. Определены положительные и негативные тенденции функционирования отрасли, выделены основные проблемы ее развития.

Определено значение стратегического управления, как современной модели управления и эфффективного способа реакции предприятия на изменение внешней среды и его внутренних возможностей.

Приведена классификация стратегий как по иерархии, так и по конкурентным признакам, а также выявлены основные компоненты этих стратегий и их содержание. Определено место каждого вида стратегий в системе стратегий предприятия, что особенно важно для принятия правильных управленческих решений. Определены роль и место функциональных стратегий предприятия, таких как: маркетинговая, производственная, финансовая, организационных изменения, социальная, НИОКР и экологическая.

Определены направления стратегического развития предприятий винодельческой отрасли, разработана система функциональных стратегий для винодельческого предприятия и предоставлены предложения по разработке стратегической альтернативы на примере ООО «ПТК Шабо».

Предложены мероприятия в рамках стратегического набора по каждой функциональной стратегии на ООО «ПТК Шабо». В результате исследования определена ведущая роль маркетинговой стратегии, в которой предлагаются мероприятия по расширению ассортимента, выходу на новые рынки, совершенствованию ценовой политики и стимулированию сбыта, открытию новых фрилиалов и др.

Ключевые слова: стратегическое управление, функциональная стратегия, винодельческая отрасль, виноделие, система стратегий.

\author{
Ageieva I. \\ Ph.D., Associate Professor \\ Department of Management and Logistics \\ E-mail: agejeva@ukr.net \\ ORCID ID: 0000-0002-9493-5493 \\ Agarkova 0. \\ Head of the Laboratory \\ Department of Management and Logistics \\ Odessa National Academy of Food Technologies \\ Kanatna str., 112, Odessa, Ukraine, 65039 \\ E-mail: violaagarkova@gmail.com \\ ORCID ID: 0000-0001-7261-7120
}

\section{IMPLEMENTATION OF FUNCTIONAL STRATEGIES AT WINERIES}

The article discusses the current state of the wine industry, namely, a comparison of the regions of Ukraine for the production of wine materials. The positive and negative trends in the functioning of the industry have been identified, the main problems of its development have been highlighted.

The importance of strategic management as a modern model and management model and an effective way of enterprise response to changes in the external environment and its internal capabilities has been determined. 
The classification of strategies has been presented both by hierarchy and by competitive attributes, and the main components of these strategies and their contents have been identified. The place of each type of strategy in the system of enterprise strategies has been determined, which is especially important for making the right managerial decisions. The role and place of the functional strategies of the enterprise, such as: marketing, production, financial, organizational changes, social, $R \& D$ and environmental, have been determined.

The system of types of strategies has been given, the constituent components of these strategies have been determined. The directions of the strategic development of the enterprises of the wine industry have been identified, a system of functional strategies for the winery has been developed, and proposals for the development of a strategic alternative have been presented on the example of LLC PTK Shabo.

Measures have been proposed as part of a strategic functional set for each functional strategy at PTK Shabo LLC. As a result of the study, the leading role of the marketing strategy has been determined, which proposes measures to expand the assortment, enter new markets, improve pricing policies and stimulate sales, open new branches, etc. strategies.

Key words: strategic management, functional strategy, wine industry, winemaking, system of

\section{References}

1. World Statistics of the Wine Institute. Retrieved September 15, 2019, from http://www.wineinstitute.org/resources/statistics.

2. 15 Of The Most Effective Wine Marketing Tactics. Retrieved September 20, 2019, from https://marketing.sfgate.com/blog/15-of-the-most-effective-wine-marketing-tactics

3. Aaker, D. A. (2013). Strategic Market Management. Wiley.

4. Mockler, R. J. (1992). Strategic Management: An Integrative Context-Specific Process. HarrisburgLondon: Idea Group Publishing.

5. Wright, P. L., Pringle, C. D., \& Kroll, M. J. (1992). Strategic management: text and cases. Boston: Allyn and Bacon.

6. Publykatsiia dokumentiv Derzhavnoi Sluzhby Statystyky Ukrainy. (n.d.). Retrieved September 5, 2019, from https://ukrstat.org

7. Mozolenko, M. S. Funktsionalni stratehii v zahalnoorhanizatsiinomu rozvytku pidpryiemstva. Retrieved September 5, 2019, from http://dspace.nuft.edu.ua/jspui/bitstream/123456789/21462/1/23.pdf

8. Prysiazhniuk, M. V., Zubets, M. V., Sabluk, P. T., Mesel-Veseliak, V. Y., \& Fedorov, M. M. (Eds.). (2011). Ahrarnyi sektor rozvytku Ukrainy (stan i perspektyvy rozvytku). Kyiv: NNTs IAE.

9. Holovne upravlinnia statystyky v Odeskii oblasti. Retrieved September 11, 2019, from http://www.od.ukrstat.gov.ua

10. Ahieieva, I.M., \& Milieva, M.D. Stratehiia konkurentsii yak osnova dosiahnennia konkurentnykh perevah kharchovykh pidpryiemstv. $\quad$ Retrieved $\quad$ September $11, \quad 2019$, from http://www.nbuv.gov.ua/old_jrn/Soc_Gum/Ekhp/2009_3/st6.pdf.

11. Aheieva, I. M., \& Aharkova, O. V. (2017). Doslidzhennia stratehii rozvytku na pidpryiemstvakh vynorobnoi haluzi. Ekonomika Kharchovoi Promyslovosti, 9(4), 35-42. doi: 10.15673/fie.v9i4.741

12. Aheieva, I. M., \& Aharkova, O. V. (2018). Planuvannia rozvytku pidpryiemstva na osnovi rozrobky stratehichnoho naboru. Ekonomika Kharchovoi Promyslovosti, 10(2), 60-68. doi: 10.15673/fie.v10i2.961

13. Krusir, H.V., \& Sokolova, I.F. (2012). Tverdi vidkhody - ekolohichni aspekty vynorobnoho pidpryiemstva. Ekolohichna bezpeka, (2), 112-115.

Received 30 September 2019

Approved 14 October 2019

Цитування згідно ДСТУ 8302:2015

Available in Internet 26.12.2019

Агеєва І.М., Агаркова О.В. Впровадження функціональних стратегій на підприємствах виноробної галузі // Економіка харчової промисловості. 2019. Т.11, вип. 4. С. 51-57. doi: 10.15673/fie.v11i4.1546

Cite as APA style citation

Ageieva, I., \& Agarkova, O. (2019). Implementation of functional strategies at wineries. Food Industry Economics, 11(4), 51-57. doi: 10.15673/fie.v11i4.1546 